\title{
A Historical and Comparative Analysis of Colonial and Post-Colonial Bureaucracy in Nigeria
}

\author{
Emmanuel Jude Abiodun Akinwale, $\mathrm{PhD}$ \\ Department of Business Administration, School of Management and Business Studies, \\ Yaba College of Technology \\ Email: abiodun_akinwale@yahoo.com, Mobile: 08023068147
}

Accepted: May 19, 2014

Doi:10.5296/ jpag.v4i2.5602 URL: http://dx.doi.org/10.5296/ jpag.v4i2.5602

\begin{abstract}
The purpose of this paper is to examine the historical and comparative analysis of colonial and post-colonial civil service in Nigeria and to probe issues connected with Nigerianisation of the civil service. It attempts to justify that both colonial and post-colonial civil service recorded bureaucratic successes but quota and federal character policies partly affected post-colonial bureaucratic practice in Nigeria. The paper applies historical and comparative analysis of colonial and post-colonial civil service in Nigeria. The paper finds that colonial administration introduced representation of indigenous officials in administration and recognized the strength of the merit principle in the practice of representative bureaucracy in Nigeria but post-colonial administration mixed meritocracy with federal character and quota policies. The paper presents elaborative discussions on strategies to break up the power hegemony of national executive with constitutional provisions of federal character policy and effects of its application subsumed in the analysis that administrative decentralization has its flaws.
\end{abstract}

Keywords: Colonial administration, Nigerianisation, regional representation, federal character, quota system 


\section{Background Issues}

Nigeria's antecedents of historical and political process dates back to colonial rule and with three major ethnic groups of Hausa- Fulani (North), the Yoruba (Southwest) and the Igbo of the Southeast. Other minorities also exist. This formed the basis of Nigeria's three regional structure and antecedents of her ethnic considerations (Mustapha 2006). Colonial administration of Nigeria had positive investments for Nigeria since 1861 and the creation of departments such as Judicial, Police, Prisons, Public Works, Customs, Posts and Telegraph, Marine and Mines that featured in 1906 were evidence of colonial civil service accomplishments (Tamuno, 1972:394) discloses other bureaucratic developments in the colonial administration of Nigeria to include the amalgamation of the Lagos Colony and Protectorate of Southern Nigeria. The Solaru Parliamentary Committee on Nigerianisation (1958/1959) accelerated the pace of Nigerianisation of the Federal Civil Service (Tamuno 1984:397). Government accepted the recommendations of the Solaru Parliamentary Committee and as at October 1, 1960, the newly-independent Nigeria led by Prime Minister Tafawa Balewa commenced the implementation of the Nigerianisation policy in the Federal Civil Service (Olusanya, 1975:66).

\subsection{Governance and Meritocracy in Colonial Administration}

Colonial administration in Nigeria created an opportunity for partnership between Nigeria and Britain. It introduced good governance structure as it partly succeeded in transforming native customs and institutions such as improvement in medical care, education, infrastructure and administrative reforms. The administration noted the unity of Nigeria despite the diverse nature of her peoples and also recognized the strength of the merit principle in the practice of representative bureaucracy in Nigeria. The administration also recognized ethnic regionalism existing among the north, southwest and east and in the colonial administrative practice; the indirect rule policy laid the foundation for the acceptance of peoples of the three regions as one. Bureaucratic inequalities among the three regions were the basis for recruitment policies from colonial to post-colonial administrative periods. Regionalism was entrenched during colonial rule as economic structures such as the marketing boards were regionalized and regional parliaments were also introduced. Meritocracy was not abandoned during colonial era as the economic and political structures recognized the importance of merit in recruitment. The problem connected with colonial bureaucracy was that of difficulty to remove the ethnic structures. (Barnes 1997:223; Graham, 1966; Adamu, 1973) cited in Mustapha (2006:8). Okeke (1992:23) cited in Mustapha (2008:8) also provides educational benefits connected with early contacts of southerners with Europeans. Thus, in 1947, the South had 13,473 primary schools with 2,343,317 pupils while the North had 2080 schools and185, 484 pupils and this explains a gap in secondary school leavers.

\subsection{Era of indigenous rule and evolution of the quota system}

By the 1950s, British colonial administration in Nigeria started to pave the way for localism of the Nigerian civil service which was achieved in 1960.The vacuum created in the administration of the Nigerian Federal Civil Service with the departure of colonial 
administrators meant that competent Nigerian administrators had to be placed in prominent positions in the Federal Civil Service. The quota system in Nigeria aimed at representation of states in federal institutions and dates back to management of the military by colonial administration when its lower echelons were occupied by ethnic minority groups from the North. In 1958, the North had 50\% of entrants to the Nigerian army and 25\% went to the East and West (Adekanye, 1989:232) cited in Mustapha (2006:33). The Nigerian civilian government of Balewa applied merit for recruitment of indigenous corps officers that took over from the British officers (Miners 1971:97-116) cited in Mustapha (2006;33). Mustapha (2006:34) notes that the military quota was later put in abeyance but later appeared into the main stream of nation-building process under the 1979 Constitution when quota was based on state. He adds that quota system introduced into the educational system comprises academic merit, educationally less developed states, catchment area and discretion by operators of respective institutions. These components had graduated scores attached to them. Albeit, the quota policies have not achieved the expectations of opportunities spread across states of the Nigerian federation. (Yoloye 1985:68) cited in Mustapha (2006). Academic merit prescribed by the quota system was based on performance at mandatory or qualifying examinations. There were also scores for educationally less developed states and the catchment area of each institution was prescribed by the government and presented to the institutions. (Suberu 2001, Yoloye 1989, Oyovbaire 1983) cited in Mustapha (2006:34). The quota system has both its merits and demerits in all sectors introduced. One merit of the quota system is the wide representation of states of the federation in federal establishments. Second, it has partly assisted to sustain the unity of the country and has also assisted to reduce gap in national development. The demerits include non-compliance with the quota system in some states, falsification of states of origin and unavailability of candidates to fill their quota in respective states of the federation. Also, the system has not been able to harmonize merit and ecological approaches. These observations explain that decentralisation is good in federal states like Nigeria and it has helped maintain the unity of the country but problems of harmonization with merit principles has introduced mediocrity and incompetence from the base of educational sector to the administrative sector. Thus, revealing that administrative policies have its flaws.

\section{The Federal Character Policy}

At independence in 1960, Nigeria operated the West-minster Parliamentary System which laid emphasis on regionalization but lacked potentials for ethnic considerations. A very important milestone to address this issue on ethnic relations was the granting of the 1979 Constitution and its path for unity with the adoption of executive Presidency who was expected to win votes from twenty-five percent of votes cast from at least two-thirds of the states of the Nigerian federation (Constitution 1979, Section 125 and126). All aspects of the national life of Nigeria were structured to reflect the federal character. Section 14; sub-section 3 of the 1979 Constitution states:

The composition of the government of the federation or any of its agencies and the conduct of its affairs shall be carried out in such manner as to reflect the federal character of Nigeria and the need to promote national unity, and also to promote national loyalty thereby ensuring that 
there shall be no predominance of persons from a few states or from a few ethnic or other sectional groups in that government or any of its agencies.

\subsection{Overview of Concerns on Indigenous Civil Service Practices in Nigeria}

The transfer from colonial to indigenous service had positive and negative effects. It was positive as Nigerians had her indigenes in control of governance and administration leading to better understanding of needs and aspirations of Nigerians. However, with the transfer were administrative, political and organizational problems. The Nigerianisation policy had led to more descriptive representation of regions and less of merit. There were also issues about regional representation and how to get representation in federal agencies. During the period of Nigerianisation of the Civil Service, there was effective participation of southern Nigerians who possessed the educational qualifications and experience in central government functions. Their northern counterparts had less formal education, but had acquired political experience and skill under the indirect rule system, which assisted them in holding political office locally and in central administration (Blitz 1965:213). The Nigerianisation of the Civil Service when colonialism ended witnessed mixture of meritocratic and ecological approaches to the practice of bureaucracy (Olowu et al. 1997:3). The Nigerian civil service functioned effectively during colonial administration and internal efficiency of the Nigerian Civil Service was seen along the lines of merit. With transfer to indigenous rule, there were organisational and political problems arising from quota and federal character policies. Olusanya (1975:66) expresses the view that with the departure of British colonial administrators at independence of Nigeria in 1960, the approach of recruitment centered on Nigerianisation principle. There was also regionalisation of the Civil Service on ethnic consideration which affected the application of the merit principle. Gboyega (1989:169) expatiates that this gave way to recruitment of incompetent personnel. The "federal character policy" which is synonymous with the quota system is valuable in giving representation to all sections of Nigeria. However, it should not be a permanent policy as it negates standard principle of merit. Thus, any country that entrenches federal character as a recruitment policy is likely to have a measure of attraction for poor quality workforce as a result of seeking political balance in recruitment (Wahhab 2009:8). The concept of Nigerianisation meant that vacuum created by the departing colonial administrators were filled by Nigerians. However, the Nigerianisation policy extended to southernisation and northernisation policies, which meant that in the southern and northern parts of the country, civil servants from the south and north respectively, were preferred in the regional Civil Services. This culminated in a complete political issue rather than an organizational problem (Nicolson 1966:169). From this point, the concept of meritocracy in the Civil Service became an issue to resolve. However, various attempts have been made to resolve it and ecological factors have also influenced negatively the performance of Nigerians in the Federal Civil Service as the service takes into consideration recommendations for appointment by traditional rulers and does not effectively implement the federal character policy for representativeness of the diverse and populous Nigerian society. (Wahhab 2009:6; Nnoli, 1987)

The federal character principle is relevant in a diverse state like Nigeria but meritocratic considerations must not be under-estimated. The principle has been applied in terms of 
sharing of bureaucratic appointments and has culminated in a disjointed Nigerian bureaucracy. Adamolekun et al. (1991:80) posits that the federal character principle tolerates the rights of groups in a society but results in a group cohesion and elite manipulation. This view is shared by Brass (1991) who sees the federal character principle as negative to showcase individual competence. In a comparative analysis, is the examination by Kiragu (1998:5) of the performance of indigenes in South Africa. He discloses the application of merit principles and practices in public service appointments with the objective of restoring the competence, motivation, integrity and accountability of civil servants. In this country, there are targeted public instruments to create more employment opportunities.

The observations from the afore-mentioned related reviews are transitional related problems during the formative period of the Nigerian Civil Service. Blitz (1965) notes a high level of internal efficiency during the early period of the Nigerian Civil Service. Concerns on poor application of the federal character principle were advanced by Mustapha (2006), Adamolekun (1991), Nnoli (1987), Oyovbaire (1983) and Kiragu (1998). Briggs (2007) provides reasons for overstaffing of the Nigerian Civil Service during her maturity period due to high rate of retrenchment by the private sector and with the impact of pressure on the Nigerian Civil Service to recruit. This poorly affects the application of the merit principle as pressure on government to recruit makes the application of the merit principle vulnerable and affecting the effectiveness of the Federal Civil Service at all levels. The commonality of quota policies in Africa is the placement of ecological factors over merit strands. The main challenges of the Nigerian Civil Service are the poor application of the federal character policy, aimed at introducing a representative bureaucracy.

\subsection{Service Delivery Reform (2003)}

The federal civil service is provided with policies that emphasize uniformity, standardization and transparency (Babura 2003:20). As part of continuous reform of the civil service, the Federal Government of Nigeria introduced a reform agenda in the public service in 2003 with a view to improving the service. Government reviewed the performance of the civil service and with assessment of public service delivery as poor; President Olusegun Obasanjo decided to strengthen the accountability and responsiveness of government through the Service Delivery Initiative (SDI) in June 2003. A report was commissioned in June 2003 to address among other things, the repositioning of the public service with a view of meeting the welfare needs of the public. Efforts to entrench the service delivery programme led to the arrangement of a special presidential retreat in March 2004. At the end of the retreat, the President and the Ministers introduced the service compact (SERVICOM) to transform the public service and redirect customer's experience of the service. The service compact aimed at provision of better services in a transparent, timely and cost effective manner (Okechukwu 2005: 9).

\subsection{National Economic Empowerment and Development Strategy (2003)}

Part of the reform agenda of President Olusegun Obasanjo was the National Economic Empowerment and Development Strategy (NEEDS) which was launched in June 2003. The main focus of NEEDS with reference to its document includes: 


\author{
Wealth Creation. \\ Employment Generation. \\ Poverty reduction, and; \\ Value re-orientation.
}

The reform extended to the states with the State Economic and Empowerment Strategy (SEEDS) which focused on issues of underdevelopment at the state level. SEEDS was also interdependent with aspects of development at the Local Government Level. Both state and local governments were to address issues of policy formulation from grassroots which is the local government of the state. Both local and state governments were to play complimentary roles in ar eas of public interest such as wealth creation and within the ambit of NEEDS. Thus, wealth creation, employment generation, poverty reduction and value reorientation were to be addressed (NEEDS Document, 2004:5). The democratic dispensation in Africa continues to stabilize and in countries such as Nigeria and Ghana, the democratic stability has created the platform for series of reforms useful for national development. Giovanne (2011) notes that advent of democracy provides valuable basis for social change and observes health reforms introduced through democratization in Ghana introduced social change which has to occur if Africa is to translate into a world-class economy.

\title{
2.4 Building of theories relevant to administrative transfer from colonial to indigenous bureaucracy
}

A theoretical framework of analysis includes the group theory building with emphasis on change process. The change from colonial to indigenous rule explains that Nigerians as citizens were in charge of their Civil Service. Groups specialize in different activities but the leaders of groups have responsibilities of directing groups and reporting them (Lathan 1965: 36). Similarly, Lloyd (1975:157) notes that the new patterns of central government, educational and legal systems that emerged in West African states, reflected signs of the prerequisites of modern and industrial societies. A comparison of colonial and indigenous administrative skills portrays foundation achievement by the colonial administration. According to Lloyd (1975:157) the colonial period provides the impetus for political growth of West African states and also provides them with the infrastructure necessary for future economic and social development. With the attainment of independence, growth and development of African states increased. Lloyds' focus was not on the degree to which African states could borrow from the West, but on the speed and smoothness with which they modified indigenous institutions. This paper on movement from colonial to indigenous Civil Service in Nigeria through a focus on comparative assessment of transitional trends reflect Lloyds view on incompatibilities as Lloyd discusses conflict and functional theories of society as reflecting social change due to incompatible roles or interest. The conflicts and compatibilities provided by Lloyds include the corrupt influence of African societies placing individual interest over common good with negative values that affects development. This corrupt influence is common in Africa. Kenya's National Rainbow Coalition (NARC) took steps to check misappropriation of public lands allocated without due process by government 
in 2012. The Commission of Enquiry into Illegal and Irregular Allocation of Public Land observed among other things that public land was allocated without public interest. The aspect of constitutionalism was introduced through appointment of an experienced lawyer; Paul Ndung'u to investigate and make recommendations and his report notes that legal officials exploited their professional skills to amass public land (Manji 2012). This negates the regard to the rule of law and a negative influence on the much expected social change in Africa.

The lessons that we draw from Lloyd (1966) and Manji (2012) is that there is low level of growth and development in Africa. This is caused by corruption, misappropriation and embezzlement of state fund and property. This discourages the industrialized world from assisting with grants and aid which had been part of the propelling factors for development in Africa. The puzzle in this practice of corruption is that Africa has the conditions for transformation to the level of industrialized nations but problems of transition occasioned by negative influences on social change affects positive transition. These conflicts and incompatibilities in Nigeria are seen in her manpower problems characterized by constraints of internal efficiency such as problems of productivity, corruption, incompetence of personnel, poor attitude to work, displacement by technology and poor leadership.

\section{Field survey and results of questionnaires on post-independence Nigerian Civil Service practices}

During the post-independence period, some improvements in Civil Service administration occurred. This paper utilizes the descriptive research design and employs both the quantitative and qualitative research methods in order to compare both colonial and post-colonial administration. A total of seven hundred federal civil servants were provided with questionnaires in seven federal ministries including the office of the Head of Civil Service of the federation. The average sizes of respondents total one hundred per ministry.

\subsection{Administration of questionnaire}

One hundred questionnaires per ministry were distributed to the seven ministries in Abuja (the capital of Nigeria) that include Federal Ministry of Establishments and Pensions, Federal Ministry of Information and Communication, Office of Head of Civil Service of the federation, Federal Ministry of Finance, Commerce and Industry, Education and Health. A total of 547 out of 700 questionnaires administered, representing $78.14 \%$ were completed and returned. However, the remainder totaling 153 (21.86\%) were unreturned. The questionnaires were also distributed randomly among top, middle and low level management workers as follows:

(i) Respondents from top management level of workers-261 (47.71\%)

(ii) Respondents from middle management of workers-184 (33.64\%)

(iii) Respondents from Low level management level of workers-102 (18.65\%)

Questionnaires distributed to policy makers in the Federal Civil Service related to issues on transition from colonial to indigenous Civil Service. Respondents were asked to provide 
answers to questions that the Nigerian Civil Service is affected by inheritance of colonial administration, heavy reliance on bureaucratic practices and constraints of enforcement of policies. Results show lack of tradition and experience on the part of Nigerian bureaucrats, proliferation of the Civil Service, impact of national policies and issues, and lack of social and economic development affected post-colonial civil service in Nigeria.

\section{Opinions of policy makers on transition from colonial to indigenous civil service}

Table 1.1: Opinions of respondents that policy implementation in the federal civil service is affected by inheritance of colonial administration, heavy reliance on bureaucratic practices and constraints of enforcement of policies.

\begin{tabular}{|l|l|l|}
\hline Variable & Respondents & Percentage (\%) \\
\hline Strongly agree & 107 & 19.56 \\
\hline Agree & 278 & 50.82 \\
\hline Disagree & 70 & 12.80 \\
\hline Strongly Disagree & 92 & 16.82 \\
\hline Total & $\mathbf{5 4 7}$ & $\mathbf{1 0 0 . 0 0}$ \\
\hline
\end{tabular}

Source: Data administered by the author, 2011

Table 1.1. shows that although $162(29.62 \%)$ of the respondents disagree, the majority representing the highest number of respondents $385(70.38 \%)$ agree that policy implementation in the Federal Civil Service is affected by inheritance of colonial administration, heavy reliance on bureaucratic practices and constraints of enforcement of policies.

\subsection{Extent of effectiveness of colonial and indigenous administration}

From the survey on assessment of colonial and indigenous administrations, it was observed that the involvement of Nigerians in the transfer to indigenous administration was a deliberate policy adopted with the main aim of replacing Europeans who manned prominent positions in the Nigerian Federal Civil Service before 1960. The federal character policy is also a constraint to the implementation of recruitment policies in Nigeria. This policy can be justified from the angle of representativeness of all the thirty (36) states in Nigeria in public sector operations and practices. Adoption of meritocratic approach in public sector operations without reference to federal character policy will affect the sustenance of national integration. However, the federal character policy over-emphasizes sharing of vacancies in recruitment to application of merit. The Federal Civil Service of Nigeria will attain giant strides in her operations with harmonious application of merit, federal character, quota, representativeness and vacancy needs in the implementation of personnel policies in Nigeria. 


\section{Conclusion}

The colonial administration applied representation of indigenous bureaucrats and gave regard to the merit principle despite the ethnic structure of the country. Quotas and federal character were not applied during the colonial period. The distinctive aspect of the transition was the mixture of meritocratic and ecological approaches by bureaucrats in the post-colonial era. Despite the institutional framework to reforming ethnic considerations by post-colonial administration, the Nigerian civil service has reached giant strides but problems of application of federal character has impeded the level of world class civil service it would have reached. Professionalism in the civil service whose foundation was laid by colonial administration is now affected by sectionalism, ethnicity and regional considerations. It is clear that with federalism, there are still politic al issues of regionalism that are unresolved. Thus, the Nigerian federal civil service needs continuous reforms to ensure more power sharing away from the centre where economic and political powers are concentrated.

\subsection{Recommendations}

\section{Harmonization of meritocratic and ecological approaches in post-colonial administration}

The problem of non-application of merit in the implementation of the federal character principle is ascribed to the failure of bureaucrats to strictly adhere to the inter-dependent application of the principle of merit and quota. The paper finds that when the federal character principle is applied to recruitment, it de-emphasizes merit. However, the framers of the federal character policy did not intend to sacrifice merit in its implementation but to ensure that both merit and quota are applied across the board in the process of national integration and nation building. A major contribution of this paper is its call for a modified procedure for implementation of the federal character policy. Although, this policy has helped in uniting the diversities in Nigeria's social formation, the federal character policy has been abused in Nigeria. The policy which was formulated to bring out the best in all ethnic groups in Nigeria has been marred by political influences and conflict. This has affected political dynamics in Nigeria and has often culminated in disequilibrium in terms of the application of the policy. To reposition the application of the federal character policy, ethical standards of merit, cultural unity and choice-based selection must be put in place and harmonized in political and administrative settings.

\section{References}

\section{$\underline{\text { Articles }}$}

Adamolekun, L. and Kincaid, J. 1991. The Federal Solution: Assessment and Prognosis for Nigeria and Africa. Publius: The Journal of Federalism, pp. 173-189.

Adamu, H.1973. The North and Nigerian Unity. Gaskiya Press. Zaria.

Adekanye, J.B.(1989) The Quota Recruitment Policy: Its Sources and Impact on the Nigerian 


\section{MInstitute Macrothink $_{\text {Int }}$}

Journal of Public Administration and Governance ISSN 2161-7104

Military. In Ekeh, P.P. and Osaghae, (eds), Federal Character and Federalism in Nigeria. Heinemann, Ibadan.

Babura, A.S.M. 2003.Leading Public Service Innovation .Paper Presented at the Commonwealth, New Zealand Agency for International Development (NEAID). Wellington. February $24^{\text {th }}$ to $8^{\text {th }}$ March.

Barnes, A.E. 1997. Some Fire behind the Smoke: The Fraser Report and its Aftermath in Colonial Northern Nigeria, Canadian Journal of African Studies, Vol. 31, No. 2 in Mustapha, A.R. (2006). Ethnic Structure, Inequality and Governance of the Public Sector In Nigeria, Democracy, Governance and Human Rights Programme. Paper Number 24, United Nations Research Institute for Social Development.

Briggs, B.R. 2007. Problems of Recruitment in the Civil Service: Case of the Nigerian Civil Service. African Journal of Business Management, September 2007.

Gboyega, A. 1989. The Public Service and Federal Characte. In P.P. Ekeh and E.E.Osaghae (eds). Federal Character and Federalism in Nigeria. Ibadan: Heinemann.

Graham, S.1966. Government and Mission Education in Northern Nigeria:1900- 1919. Ibadan University Press Ibadan.

Kiragu, K. 1998. Civil Service Reforms: in Southern and Eastern Africa: Lessons of Experience'. Report on Proceedings of a Consultative Workshop held at Arusha. Tanzania. March 4-6, 1998, P. 5.

Lathan, E. 1965. The Decision Process, U.S.A. University of Maryland College, Park Md Lloyd, P.C. 1975. Africa in Social Change, Hamondsworth, Penguin Books Ltd.

Manji, A. (2012). The Grabbed State: Lawyers, Politics and Public Land in Kenya. The Journal of Modern African Studies. Cambridge. Cambridge University Press. Vol. 50, Issue 03. September 2012,pp 467- 492.

Miners, N.J. 1971. The Nigerian Army 1956-1966. Methuen, London.

Mustapha, A.R. (2006). Ethnic Structure, Inequality and Governance of the Public Sector in Nigeria, Democracy, Governance and Human Rights Programme. Paper Number 24, United Nations Research Institute for Social Development.

Nicolson, I.F. (1966). The Machinery of Federal and Regional Governments. In J.P. Mackintosh (ed.), Nigerian Government and Politics. London: Allen and Unwin.

Nnoli, O. (1990). Ethnic Politics In Nigeria. Enugu: Fourth Dimension Publishers.

Okechukwu, O. (2005). Beyond Service Charters. Lagos. New Age. June p.17.

Okeke, O. 1992. Hausa-Fulani Hegemony. Acena Publishers, Enugu.

Olowu, D. Otobo, E. and Okotomi, M. (1997). The Role of the Civil Service in Enhancing Development and Democracy: An Evaluation of the Nigerian Experience at Civil Service 


\section{Macrothink}

Journal of Public Administration and Governance ISSN 2161-7104 2014, Vol. 4, No. 2

Systems in Comparative Perspective. Bloomington, School of Public and Environmental Affairs, Indiana University.

Oyovbaire, S.E. (1983). Structural Change and Political Processes in Nigeria African Affairs. No. 326, pp. 3-28.

Suberu, R. (2001). Federalism and Ethnic Conflict in Nigeria. United States Institute for Peace Press. Washington D.C.

Wahhab, M.A. (2009). Civil Service Recruitment Policy in Bangladesh: A Critical Analysis. Paper Submitted for NAPSIMAG International Conference 2009, Malaysia, Executive Development Centre Development Centre, University Utara, Malaysia, Kedah, 11-13 December, 2009.

Yoloye, E. A. (1989), Federal Character and Institutions of Higher Learning in Ekeh, P.P. and Osagae, E.E. (eds.), Federal Character and Federalism in Nigeria. Heinemann, Ibadan.

\section{$\underline{\text { Books }}$}

Blitz, L. (1965). The Politics and Administration of Nigerian Government, London. Sweet and Maxswell.

Brass, P. R. (1991). Ethnicity and Nationalism: Theory and Comparison. New Delhi: Sage.

NEEDS Document (2004).Annex1.NEEDS Secretariat, National Planning Commission, Federal Secretariat Abuja. In Maduabum C. (2006). Reforming Government Bureaucracies in Nigeria. Badagry: ASCON Printing Press.

Olusanya, G.O. (1975). The Evolution of the Nigeria Civil Service 1861- 1960.The Problems of Nigerianization. Humanities Monograph Series. Lagos: University of Lagos.

Tamuno, G.O. (1984). British Colonial Administration in Nigeria in the Twentieth Century. In Obaro Ikime (ed). Groundwork of Nigerian History. Ibadan: Heinemann Educational Books (Nig.) Ltd. 